\title{
Georisks in the Mediterranean and their mitigation
}

\author{
Sebastiano D'Amico' ${ }^{1}$ Pauline Galea ${ }^{1} \cdot$ Ruben P. Borg ${ }^{2}$. \\ Marc Bonello ${ }^{3}$
}

Published online: 15 March 2017

(C) Springer Science+Business Media Dordrecht 2017

In recent years, geological and geo-engineering studies have achieved important improvements and advances in both the theoretical and applied aspects.

The research and findings presented in this volume contribute toward the improvement in risk mitigation measures, firstly through the observation and analysis of the various geohazards and their monitoring strategies, and also through the technical study of numerical modeling, improvement of design methods and testing practices for earthquakeresistant construction and seismic retrofitting. The ultimate goal is the application of science, technology, and shared expertise in an effort to minimize human and material losses from geohazards. The Mediterranean area is an excellent testing ground for such methodologies since the region lies in a complex tectonic setting resulting in a high-risk exposure (D'Amico et al. 2013) that has manifested itself in the unfortunate loss of many thousands of lives.

In the framework of the SIMIT (Integrated Civil Protection System for the ItaloMaltese Cross-Border Area,) project, the University of Malta organized a scientific conference in 2015, entitled "Georisks in the Mediterranean and their Mitigation," aiming to bring together experts and researchers in various fields, such as geology, geophysics, geohazards, civil engineering, and civil protection to discuss theories, methodologies, and case studies for understanding, modeling, forecasting, and mitigating the effects of perilous natural events and their impact on society (Galea et al. 2015). SIMIT was a €2.5-million Strategic Project funded by the Italia-Malta 2007-2013 operational program under priority axis II-environment, energy, and risk prevention. The lead partner was the Regional Civil Protection Department of Sicily, while the other four partners were the Universities of

Sebastiano D'Amico

sebastiano.damico@um.edu.mt

1 Department of Geosciences, University of Malta, Msida Campus, Msida MSD2080, Malta

2 Department of Construction and Property Management, University of Malta, Msida Campus, Msida MSD2080, Malta

3 Department of Civil and Structural Engineering, University of Malta, Msida Campus, Msida MSD2080, Malta 
Palermo and Catania, the Civil Protection Department of Malta, and the University of Malta. SIMIT worked toward the establishment of an integrated system which will facilitate the evaluation, forecasting, prevention and mitigation of losses from geological hazards affecting the Sicily Channel. This has been done through a virtual common operations room, comprising efficient networking and a dedicated portal for rapid exchange of information, and by disseminating a culture of risk awareness and emergency management procedures. Although the project focused on the risks within the Sicily channel, the conference widened the scope to a larger area to include geohazards affecting the wider Mediterranean region. This special issue contains 20 research articles (mainly presented during the conference) that span over a wide range of topics such as:

- geological hazards;

- seismic hazard and risk;

- geophysical application to study site effects and landslides;

- seismic monitoring;

- seismic vulnerability;

- coastal vulnerability;

- public perception of risks and geoethics.

Baldassini and Di Stefano (2017) present a detailed study about the stratigraphy of the Maltese archipelago gathered by using a large amount of existing and unpublished data which allow a detailed and complete definition of the stratigraphic features of Maltese Archipelago sedimentary succession highlighting new insights into the tectonic setting of the Central Mediterranean region. Cavallaro et al. (2017) and Cultrera et al. (2017) used integrated analysis of field structural geology coupled with geophysical and seismological data to provide a structural re-evaluation of the seismic and geomorphological hazard, linking their findings with the seismic hazard in the central Mediterranean region. Hamdache et al. (2017) propose statistical analysis as a first step to contribute to regional seismic hazard computation providing detailed information on maximum regional magnitudes, characteristics of spatial clustering, and distribution of seismic energy release for the Algerian area. Nappi et al. (2017a, b) present the geologic-geomorphologic ground effects due to the strong 1743 Salento earthquake with the main aim to provide a positive contribution to the seismic hazard assessment of the Salento Peninsula (Apulia, southern Italy) which, despite the occurrence of several moderate-to-large earthquakes, is not considered as an area with high seismic hazard. Several papers in this special issue describe the use of geophysical applications and techniques to address hydrogeological risks such as landslides (Imposa et al. 2017; Capuano et al. 2017), evaluation of seismic site response (Panzera et al. 2017; Albarello et al. 2017), and the evaluation of ground subsidence in historical city centers (Leucci et al. 2017). Capuano et al. (2017) propose a new procedure to analyze continuous seismic volcano-tectonic events throughout the insurgence of seismic activity. Pesaresi et al. (2017) describe the implementation of an early-warning system in the cross-border area among Italy, Austria, and Slovenia. Four papers in this special issue are devoted to the evaluation of seismic risk (Hamidatou and Sbartai 2017), vulnerability of masonry buildings (Formisano 2017; Ferraioli et al. 2017), and urban areas in the central Mediterranean region (Cavaleri et al. 2017). Deguara and Gauci (2017) present an in-depth analysis of boulder deposits, located along the SE coast of the Maltese archipelago showing that the area is exposed to strong storm waves that are capable of displacing some of the very large boulders observed on site. Finally, the last two papers deal with resilience and seismic risk perception (De Pascale et al. 2017) and 
perception on coastal erosion as well as awareness toward coastal processes and their impacts on society (Farrugia 2017).

The Guest Editors believe that this special issue will contribute to the ongoing discussion and knowledge transfer in the field of geohazard evaluation and the mitigation of risk.

Acknowledgements The Guest Editors are grateful to all the authors for their close cooperation while preparing their contributions. They also gladly acknowledge all the referees, belonging to a number of research institutions located worldwide. Their careful reading and constructive suggestions contribute to the standard of the final versions presented in this special issue of Natural Hazards. Special thanks go to the Editor-in-Chief Prof. Thomas Glade and the Journal staff for their professional assistance and technical support during the entire publishing process that has led to the realization of this special issue.

\section{References}

Albarello D, Francescone M, Lunedei E, Paolucci E, Papasidero MP (2017) Seismic characterization and reconstruction of reference ground motion at accelerometric sites of the Italian national accelerometric network (RAN). Nat Hazards. doi:10.1007/s11069-016-2310-4

Baldassini N, Di Stefano A (2017) Stratigraphic features of the Maltese Archipelago: a synthesis. Nat Hazards. doi:10.1007/s11069-016-2334-9

Capuano P, De Lauro E, De Martino S, Falanga M, Petrosino S (2017) Convolutive independent component analysis for processing massive datasets: a case study at Campi Flegrei (Italy). Nat Hazards. doi:10. 1007/s11069-016-2545-0

Cavaleri L, Di Trapani F, Ferrotto MF (2017) A new hybrid procedure for the definition of seismic vulnerability in Mediterranean cross-border urban areas. Nat Hazards. doi:10.1007/s11069-016-2646-9

Cavallaro D, Monaco C, Polonia A, Sulli A, Di Stefano A (2017) Evidence of positive tectonic inversion in the north-central sector of the Sicily channel (Central Mediterranean). Nat Hazards. doi:10.1007/ s11069-016-2515-6

Cultrera F, Barreca G, Burrato P, Ferranti L, Monaco C, Passaro C, Pepe F, Scarfi L (2017) Active faulting and continental slope instability in the Gulf of Patti (Tyrrhenian side of NE Sicily, Italy): a field, marine and seismological joint analysis. Nat Hazards. doi:10.1007/s11069-016-2547-y

D'Amico S, Lombardo G, Panzera F (2013) Seismicity of the Mediterranean Region and mitigation of earthquake losses. Phys Chem Earth 63:1-2. doi:10.1016/j.pce.2013.07.001

De Pascale F, Bernardo M, Muto F, Di Matteo D, Dattilo V (2017) Resilience and seismic risk perception at school: a geoethical experiment in Aiello Calabro, southern Italy. Nat Hazards. doi:10.1007/s11069016-2696-z

Deguara JC, Gauci R (2017) Evidence of extreme wave events from boulder deposits on the south-east coast of Malta (Central Mediterranean). Nat Hazards. doi:10.1007/s11069-016-2525-4

Farrugia MT (2017) Public perceptions on coastal erosion in the Maltese Islands: a case study of St George's Bay (St Julians) and Pretty Bay (Birżebbuga). Nat Hazards. doi:10.1007/s11069-017-2775-9

Ferraioli M, Miccoli L, Abruzzese D, Mandara A (2017) Dynamic characterisation and seismic assessment of medieval masonry towers. Nat Hazards. doi:10.1007/s11069-016-2519-2

Fiorucci M, Iannucci R, Lenti L, Martino S, Paciello A, Prestininzi A, Rivellino S (2017) Nanoseismic monitoring of gravity-induced slope instabilities for the risk management of an aqueduct infrastructure in Central Apennines (Italy). Nat Hazards. doi:10.1007/s11069-016-2516-5

Formisano A (2017) Local- and global-scale seismic analyses of historical masonry compounds in San Pio delle Camere (L'Aquila, Italy). Nat Hazards. doi:10.1007/s11069-016-2694-1

Galea P, Borg RP, Farrugia D, Agius M, D'Amico S, Torpiano A, Bonello M (eds.), 2015. Proceedings of the international conference: georisks in the Mediterranean and their mitigation. Mistal Service Press, ISBN:978-88-98161-20-1 (available online at http://www.mistralservice.it/Proceedings-ofInternational-Conference-georisks-in-the-Mediterranean-and-their-mitigation_B_38.html)

Hamdache M, Peláez JA, Kijko A, Smit A (2017) Energetic and spatial characterization of seismicity in the Algeria-Morocco region. Nat Hazards. doi:10.1007/s11069-016-2514-7

Hamidatou M, Sbartai B (2017) Deterministic assessment of seismic risk in Constantine city, Northeast Algeria. Nat Hazards. doi:10.1007/s11069-016-2693-2

Imposa S, Grassi S, Fazio F, Rannisi G, Cino P (2017) Geophysical surveys to study a landslide body (northeastern Sicily). Nat Hazards. doi:10.1007/s11069-016-2544-1 
Leucci G, De Giorgi L, Gizzi FT, Persico R (2017) Integrated geo-scientific surveys in the historical centre of Mesagne (Brindisi, Southern Italy). Nat Hazards. doi:10.1007/s11069-016-2645-x

Nappi R, Gaudiosi G, Alessio G, De Lucia M, Porfido S (2017a) The environmental effects of the 1743 Salento earthquake (Apulia, southern Italy): a contribution to seismic hazard assessment of the Salento Peninsula. Nat Hazards. doi:10.1007/s11069-016-2548-X

Nappi R, Gaudiosi G, Alessio G, De Lucia M, Porfido S (2017b) Erratum to: the environmental effects of the 1743 Salento earthquake (Apulia, southern Italy): a contribution to seismic hazard assessment of the Salento Peninsula. Nat Hazards. doi:10.1007/s11069-016-2610-8

Panzera F, Lombardo G, Longo E, Langer H, Branca S, Azzaro R, Cicala V, Trimarchi F (2017) Exploratory seismic site response surveys in a complex geologic area: a case study from Mt. Etna volcano (southern Italy). Nat Hazards. doi:10.1007/s11069-016-2517-4

Pesaresi D, Picozzi M, Živčić M, Wolfgang Lenhardt W, Mucciarelli M, Aldo E, Zollo A, Gosar A (2017) A cross-border regional earthquake early warning system: PRESTo@CE3RN. Nat Hazards. doi:10.1007/ s11069-016-2695-0 